\title{
Taktik Komunikasi Politik Partai Nasdem Dalam Memenangkan Pemilu Legislatif 2019
}

\author{
Aida Farichatul Laila1, Khoirul Muslimin ${ }^{2}$, \\ Lukman Hakim 3
}

Universitas Diponegoro Semarang, Universitas Islam Nahdlatul Ulama Jepara, IAIN Kediri aydalively@gmail.com

\begin{abstract}
This article discusses the political communication strategy of a party, especially the National Democratic Party (NasDem) in Central Java in the 2019 Legislative Election.

This study uses the Elaboration Likelihood ModelTheory from Petty and Cacciopo, when the persuasion of messages in the campaign can be accepted by the public so that they can win the 2019 Legislative Election contestation.

This study uses a postpositivism paradigm, with qualitative descriptive research methods and triangulation of data sources, while the focus of this research is on the candidates for members of the NasDem Party who are now members of the legislative in the DPRD of Central Java Province.

The results of this study indicate that the Political Communication Tactics used by the Central Java NasDem Party in winning the 2019 Election Contestation was communicating with a traditional approach by personally meeting the cloud community, organizations community, community leaders, Islamic figure (Kiai), former officials, RT and RW. Those ways were carried out by the model of house visit, 'nguwongke uwong',. The result of this study indicates that three legislative candidates who are currently sitting in the DPRD of Central Java have been elected.
\end{abstract}

Keywords : Tactics.political communication, 2019 legislative elections

\begin{abstract}
Abstrak
Penelitian ini bertujuan untuk mengetahui bagaimana strategi komunikasi politik suatu partai, khususnya pada partai Nasional Demokrat (NasDem) di Jawa Tengah pada Pemilu Legislatif 2019.

Teori yang digunakan pada penelitian yaitu Elaboration Likelihood Model Theory (ELM) dari Petty dan Cacciopo, ketika persuasi pesan-pesan dalam kampanye bisa diiterima oleh masyarakat sehingga dapat memenangkan kontestasi Pemilu Legislatif 2019.

Penelitian ini menggunakan paradigma postpositivisme, dengan metode penelitian deskriptif kualitatif dan triangulasi data. Fokus penelitian ini, yaitu calon anggota Partai NasDem yang sekarang menjadi anggota legislatif di DPRD Provinsi Jawa tengah.
\end{abstract}


Penelitian ini menyatakan bahwa Taktik Komunikasi Politik yang digunakan Partai NasDem Jawa Tengah untuk memenangkan Kontestasi Pemilu 2019 dengan cara melakukan komunikasi melalui pendekatan tradisional yaitu dengan bertemu secara personal masyarakat awam, komunitas organisasi, tokoh masyarakat, Para Kiai, mantan penjabat, RT dan RW yang dilakukan dengan model kunjungan ke rumahrumah, 'nguwongke uwong', sehingga terpilihlah tiga calon legislatif yang sekarang duduk di kursi DPRD Jawa Tengah.

Kata kunci : Taktik, komunikasi politik, caleg legislatif 2019

\section{Pendahuluan}

\section{Introduction}

Pemilihan umum (Pemilu) merupakan momen untuk menyalurkan aspirasi masyarakat terhadap pemerintah, yang berpeluang untuk menentukan siapa yang akan mewakili di pemerintahan, baik di lembaga legislatif maupun eksekutif. Pemilu digelar oleh pemerintah dengan tujuan menyeleksi para pemimpin pemerintah dan public policy. Pemilu merupakan sarana menggerakkan rakyat terhadap pemerintah dan negara dalam menjalankan proses politik melalui partai politik yang ditetapkan oleh pemerintah. Setiap Partai politik memiliki visi dan misi bersaing untuk tampil di depan publik dalam merebut hati rakyat. Partai politik harus memiliki strategi komunikasi politik untuk membentuk citra positif partai agar dapat bersaing dengan partai lain.

Politik dipandang sebagai alat dalam mempertahankan serta mendapatkan kekuasaan yang mempengaruhi banyak orang/audiens. Setiap orang berhak berpolitik, sebab setiap orang berhak membela pembangunan masyarakat dalam segala aspek kehidupan bermasyarakat. Sebagaimana tercantum dalam UUD 1945 dalam Pasal 28 yang menyatakan bahwa "kebebasan berserikat dan berkumpul untuk menyatakan pikiran secara lisan dan tertulis, dan lain-lain". diatur oleh undang-undang".

Agar dapat dukungan masyarakat, partai politik harus mampu meramu komunikasi dengan cantik, sehingga masyarakat terhipnotis dan menentukan pilihannya ke salah satu partai. Effendy (2007, hlm. 299) menyatakan bahwa taktik komunikasi adalah pedoman pelaksanaan dan planning dalam mengatur pola hubungan komunikasi untuk menggapai target yang diinginkan.

Pentingnya taktik berstartegi dalam kontestasi politik menentukan berhasil tidaknya sebuah partai. Sebuah penelitian dari Afirman Ngato menyatakan bahwa strategi kemenangan yang digunakan partai Demokrat tahun 2014 di Pulau Marota menggunakan pendekatan interpersonal (antarpribadi). Dianggap berhasil karena pendekatan dengan langsung menemui audien (face to face) kedetakan emosionalnya akan lebih terbentuk antara caleg dengan konstituen. Penentuan strategi komunikasi politik yang tepat sasaran akan memudahkan seorang kandidat atau sebuah partai dalam mempengatuhi hati masyarakat pemilih untuk meraup suara. 
Hal serupa juga diungkapkan oleh Harold Y. Pattiasina dalam penelitiannya yang mengungkapkan bahwa strategi komunikasi politik yang dilakukan Partai PDI Perjuangan di Maluku tahun 2014 menggunakan pendekatan media massa. Penyebaran pesan lewat media massa dinilai paling efektif dalam penyebaran informasi persuasi. Materi pesan politik yang disampaikan caleg adalah solusi atas permasalahan yang dihadapi masyarakat. Pesan politik harus menyertakan visualisasi mengenai dampak positif atas respons tertentu yang diharapkan muncul dari masyarakat pemilih. Melalui pesan politik ini, masyarakat akan merasa dekat dan memiliki sikap positif terhadap caleg tersebut. Sedangkan dari sisi struktur pesan, perlu menyertakan sisi pesan, susunan penyajian dan pernyataan kesimpulan agar pesan politik yang disampaikannya efektif mempengaruhi masyarakat pemilih.

Di indonesia, Pemilu telah diadakan sebanyak dua belas kali sejak tahun $(1955,1971$, 1977, 1982, 1987, 1992, 1997, 1999, 2004, 2009, 2014, dan 2019). Menurut KPU pada Pemilu tahun 2019, ada 14 partai politik yang lolos verifikasi, dan mengikuti pesta demokrasi, salah satunya adalah partai NasDem. Partai NasDem sendiri sejak berdiri, baru mengikuti dua kali Pemilu yaitu tahun 2014 dan 2019.

Partai NasDem merupakan Partai yang lahir dari organisasi sosial demokrasi nasional yang dipimpin oleh Surya Paloh. Lahirnya partai NasDem tidak lepas dari visi dan misi utama organisasi demokrasi nasional, yaitu menggalang gerakan Perubahan Restorasi Indonesia. Restorasi Indonesia merupakan gerakan yang bertujuan mengembalikan, dan memajukan fungsi pemerintahan Indonesia dalam cita-cita proklamasi 1945. NasDem bertekad memajukan Negara Kesatuan Republik Indonesia melalui empat cara yaitu yaitu: (1) memperbaiki; (2) mengembalikan, memulihkan; dan (3) mencerahkan. Pada 7 Januari 2013, Nasdem memenuhi persyaratan verifikasi faktual di semua provinsi.Visi Nasdem adalah mengembalikan tujuan negara sebagaimana tertuang dalam Pembukaan UUD 1945, yaitu negara yang merdeka, bersatu, berdaulat, adil dan makmur.

Partai NasDem sebagai partai baru telah memperoleh suara sebanyak 8.402.812. sedangkan pada tahun 2019 mendapat perolehan suara sebanyak 12.661.792. Kemudian partai NasDem di Jawa Tengah memperolah suara sebanyak 775.963 sedangkan pada tahun 2019 mendapat perolehan suara sebanyak 1.496.325. Bisa diartikan bahwa partai NasDem di Jawa Tengah mengalami peningkatan 2 kali lipat.

Tabel. 1 Perolehan suara Partai NasDem Jawa Tengah

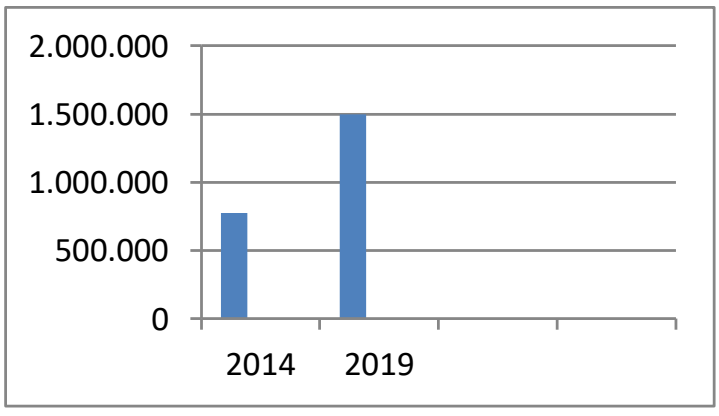


Kenaikan suara signifikan yang diperoleh partai NasDem menunjukkan bahwa sebuah partai memiliki strategi komunikasi politik dalam kemenagannya. Strategi komunikasi yang tepat dapat membuat partai politik mempertahankan eksistensinya dalam proses pemilihan umum. Sebab strategi yang tepat akan menentukan hasil yang baik, karena setiap peperangan tanpa strategi ibarat membuang garam ke dasar samudra.

Penelitian ini bertujuan untuk mengetahui bagaimana strategi komunikasi politik yang dilakukan partai NasDem dalam kontestasi Pemilu 2019 di Jawa Tengah sehingga bisa menaikkan suara hingga dua kali lipat dan memenangkan 3 Caleg dalam mendapatkan posisi sebagai Anggota Legislatif di Jawa Tengah.

\section{Method}

Metode penelitian ini dilakukan dengan pendekatan kualitatif. Penelitian dengan pendekatan kualitatif digolongkan ke dalam penelitian subjektif, reflektif atau interpretatif yang berbeda dengan penelitian kuantitatif yang objektif. Untuk desain studi kasus dalam penelitian ini, peneliti menggunakan desain yang bersifat studi kasus tunggal (single case). Dalam buku metodologi penelitian kualitatif, Sutopo mengemukakan suatu penelitian disebut sebagai studi kasus tunggal, bilamana penelitian tersebut terarah pada sasaran dengan satu karakteristik (Sutopo 2006). Artinya, penelitian tersebut hanya dilakukan pada satu sasaran (satu lokasi, atau satu subjek). Namun jumlah sasaran (lokasi studi) tidak menentukan suatu penelitian berupa berupa studi tunggal atau ganda.

Studi yang digunakan dalam penelitian ini adalah studi kasus tentang Strategi Komunikasi Politik Partai NasDem dalam Pemilu 2019 di Jawa Tengah dengan mengambil beberapa informan seperti Caleg NasDem Jawa Tengah dan praktisi politik (pengurus DPW Partai NasDem). Data dikumpulkan dengan cara wawancara mendalam yang kemudian diinterpetasi oleh penulis. Analisis data penelitian ini akan menggunakan axinal coding Neuman dalam Creswell (2007, hlm. 67), pada axial coding peneliti menggabungkan data dengan cara yang baru setelah open coding. Pada pengkodean ini, peneliti mengidentifikasi suatu fenomena sentral (central phenomenon), mengeksplorasi kondisi kausal (casual conditions), menspesifikasi strategi-strategi, mengidentifikasi konteks (context) dan kondisi yang mempengaruhi (intervening conditions), dan mendeskripsikan konsekuensikonsekuensi (consequences) untuk fenomena yang diteliti.

\section{Result and Discussion}

\section{Srtategi Pemenangan Partai Nasdem}

Strategi berbasis modalitas merupakan salah satu pemikiran yang dikembangkan oleh Piere Bourdieu. Menurutnya, kepemilikan modalitas merupakan sebuah kekuatan utama bagi setiap individu, untuk merebut dan mendapatkan kekuasaan dalam sebuah (social space) yang disebut sebagai arena kekuasaan. Namun demikian untuk mendapatkan kekuasan, modalitas memainkan peranan penting sebagai kekuatan yang menopang tiap 
individu untuk mendapatkan kekuasaan dan mendapatkan legitimasi atas kekuatan yang dimiliki. Pemikiran Bourrdieu tentang modalitas ini, selanjutnya diadopsi dan dikembangkan dalam dunia politik, terutama berkaitan dengan srategi politik sehingga modalitas seringkali dikembangkan dalam sebuah kompetisi elektoral.

Oleh karena itu, dalam ilmu politik taktik politik dapat dilakukan dengan modalitas. Modalitas ini menjadi kunci utama untuk mendulang suara di daerah. Modalitas yang dilakukan dalam taktik politik yaitu: (1) modal politik; (2) modal sosial; dan (3) modal ekonomi. Ketiga modalitas tersebut menjadi alat politik yang harus dimiliki oleh seorang kandidat, untuk bisa berkompetisi dalam pemilihan elektoral. Karena modalitas merupakan sesuatu hal paling mendasar yang merupakan keunggulan seorang kandidat legislative menurut Bourdicu (1991, hlm. 229- 231). Agar lebih detail terkait modalitas seorang aktor politik peneliti akan menguraikan 3 (tiga) modalitas.

\section{Modal Politik}

Secara teoritis modal politik yaitu berupa dukungan dari partai yang dilakukan secara kelembagaan, dan aturan partai yang mempunyai kedekatan dengan elite jabatan di struktural partai, sehingga loyalitasnya terhadap partai tidak diragukan dan disangsikan lagi. Berdasarkan kedekatan dengan elit serta jabatan di struktural partai, para kontestan ini bisa dipilah menjadi dua kategori: (1) kader yang berpindah partai; dan (2) kader partai yang setia atau loyalis. Di bawah ini akan peneliti uraikan kedekatan dengan elit serta jabatan di struktur partai.

Pertama, kader yang berpindah partai. Artinya kader yang pindah partai sering terjadi, karena akibat ketatnya persaingan di partai lama yang pada umumnya terjadi di partai besar, sehingga peluang untuk dicaleg-kan atau menempati urutan atas akan mempunyai peluang cukup kecil. Hanya yang terjadi dalam perpolitikan di Indonesia bukan ke partai yang sudah mapan, melainkan ke partai yang masih tergolong muda (misalnya Gerindra), atau partai yang baru saja dibentuk seperti Perindo. Hal tersebut dapat dipahami, bahwa partai-partai baru yang menjadi tumpuan harapan kader yang pindah ini, yaitu partaipartai yang menunjukkan prospek cerah ke depan. Parta-partai baru tersebut masih kekurangan sumber daya politisi yang berpengalaman, terutama di daerah sehingga politisi dari partai lain bisa diterima dengan tangan terbuka.

Kedua, kader partai yang setia atau loyalis. Ada beberapa alasan mengapa seorang politisi tetap loyal dalam partainya yaitu : (1) pada umumnya seorang politisi mempunyai posisi yang cukup penting dan mapan dalam partai tersebut. Oleh karena itu, karir politik yang diperoleh melalui usaha yang cukup panjang, sehingga bisa menempati posisi sebagai pengurus teras, mulai dari sekretaris tingkat satu atau tingkat dua bahkan ketua untuk tingkat kabupaten, kecamatan dan ketua tingkat provinsi; dan (2) soliditas antar pengurus dalam internal partai sehingga menjamin berjalannya proses kaderisasi secara terbuka dan transparan. Kedua kategori tersebut dapat memberikan dukungan dari partai yang dilakukan secara kelembagaan, dan aturan partai yang mempunyai kedekatan dengan elite 
jabatan di struktural partai. .Jadi modal politik merupakan bagian yang terpenting dan cukup signifikkan bagi para kontestan tersebut.

\section{Modal Sosial}

Sejalan dengan pemikiran Bourrdieu, modal sosial merupakan salah satu tuntunan utama, yang harus dimiliki oleh setiap calon legislatif untuk memenangkan sebuah proses pemilihan umum. Dalam kontestasi dan persaingan untuk mendapatkan dukungan pemilih tersebut, modal sosial merupakan salah satu rujukan utama sejauhmana calon legislatif, mampu membangun hubungan politik dengan pemilih.

Meski secara umum hubungan politik berasal dari jaringan sosial, yang melekat pada relasi-relasi sosial dan kepercayaan, yang sudah terbangun diantara kedua pihak antara calon legislatif dengan masyarakat atau pemilih.Jika hubungan yang sebelumnya hanya bersifat biasa-biasa dengan didasarkan pada relasi dan kepercayaan, maka selanjutnya dijadikan sebagai dasar untuk membangun hubungan politik.

Modal sosial adalah faktor yang sangat menentukan dalam kontestasi politik di daerah pilihan dimanapun berada. Dilihat kultur dan budaya masyarakat daerah ini terdiri dari kaum santri, abangan santri dan abangan, maka interaksi dan perilaku sehari-hari masyarakat di Jawa Tengah masih kental dengan nuansa Islami yang lekat dengan tokoh agama. Para tokoh masyarakat di daerah ini mempunyai pengaruh yang bisa menjadi sosok perekat solidarits dan peredam konflik. Para tokoh atau orang memiliki jabatan (RT, RW, Petinggi, Kiai, Modin, Ustad, Guru, Ketua Adat) di daerah dalam kehidupan sehari-hari cukup disegani dan dituruti kata-katanya, sehingga mempunyai basis massa yang luas dan cukup loyal.

Dari beberapa calon legislatif di atas, semuanya memiliki modal sosial cukup besar dan signifikan, yaitu sebagai tokoh masyarakat di daerahnya masing-masing. Sementara caleg yang terpilih di semua daerah pemilihan merupakan tokoh masyarakat, sekaligus sebagai putra daerah yang sudah cukup dikenal di lingkungan organisasi masyarakat. Jika dilihat dari posisinya para caleg yang terpilih, Para caleg yang paling kuat dibanding dengan kompetitornya, baik di internal partai maupun eksternal. Selain incumbent yang mempunyai kedudukan juga sebagai tokoh masyarakat, sehingga tetap mempunyai pengaruh terhadap basis massa di desa, serta seluruh kecamatan di daerah yang menjadi pilihannya.

"Saya itu selalu konsisten jika ada aspirasi bantuan yang diberikan kepada masyarakat, tidak ada pengurus yang melakukan pemotongan dengan sikap kepemimpinan yang tegas dan menghargai ini, akhirnya masyarakat mempercayai terhadap ide serta program-program yang dilakukan kepada masyarakat," papar Akwan.

Sedangkan keberadaan para caleg-celag yang lain hanya mempunyai basis massa dengan mengandalkan jaringan melalui relawan atau tim sukses. Pada posisi itu, Zuhar Mahsun sebagai caleg memiliki posisi strategis sebagai Wakil Ketua NasDem dan Wakil Ketua Muslimat NU Jawa Tengah, merupakan kaukus politik perempuan yang mempunyai anak 
buah dan jaringan cukup banyak di daerah pilihannya. Ditempat kelahirannya sendiri namanya sudah tidak asing lagi, bagi masyarakat Pemalang, Pekalongan, Batang serta daerah sekitarnya.Sedangkan caleg-caleg lainnya ada sebagian mempunyai kedudukan struktural di masing-masing partainya.bahkan ada caleg dari partai lain tidak merangkap sebagai pengusaha.

Dengan modal memiliki jabatan sosial itulah, Zuhar Mahsun lebih unggul dibandingkan dengan para caleg dari partai lainnya.Hal ini bisa dilihat dari posisinya yang tinggi di kepengurusan struktural Partai NasDem ini.Selain mempunyai kedekatan dengan kelompok-kelompok pengajian dan ormas perempuan yang berada di Batang daerah sekitarnya, merupakan kelompok yang paling besar jumlah para anggotanya.Perolehan suara yang tinggi tentu tidak lepas dari pengurus Muslimat Nahdhatul Ulama (NU) Jawa Tengah ini, mempunyai pengaruh cukup besar terhadap masyarakat dalam memupuk jaringan sosial.

Oleh karena itu, caleg yang aktif di berbagai organisasi ini, telah memiliki konstituen yang bisa dengan mudah dimobilisasi untuk kemenangan kontestasi dalam Pemilu. Hal yang sama dilakukan oleh Prayogo dengan sendirinya memiliki modal yang dibanggakan, berupa rekam jejak dan popularitas yang mempunyai arti penting dalam sebuah Pemilu.

Tabel 2. Caleg Terpilih di Dapil Jawa Tengah

\begin{tabular}{clcc}
\hline No & Nama Caleg & $\begin{array}{c}\text { Perolehan } \\
\text { suara }\end{array}$ & Tahun terpilih \\
\hline 1 & Akhwan & 39.446 & 2019 \\
\hline 2 & Prayogo Nugroho & 77.206 & 2019 \\
\hline 3 & Suharto & 16.529 & 2019 \\
\hline
\end{tabular}

Sumber data KPUProvinsi Jawa Tengah

Adapun para kontestan yang bukan incumbent pada umumnya mempunyai modalitas yang lain, untuk bisa melakukan penggalangan guna mencari dukungan yang selanjutnya berhasil berupa kumpulan suara.

\section{Modal Ekonomi}

Modal ekonomi sebagai salah satu modal yang khusus dikaitkan dengan kemampuan ekonomi yang dimiliki oleh seorang kandidat, ketika ikut mencalonkan diri sebagai calon legislatif. Modal ekonomi terkait dengan kekayaan atau kemampuan finansial yang dimiliki oleh para kontestan pemilu untuk maju dan terlibat dalam proses pemilihan umum berlangsung. Dalam sebuah kontestasi pemilihan umum modal ekonomi yang dimiliki, tidak hanya bersumber dari kekayaan pribadi melainkan bisa saja berasal atau bersumber dari 
dana-dana sumbangan pengusaha yang turut mencari keuntungan dari proses pemilu berlangsung.

Dilihat perkembangan demokrasi pasca reformasi proses Pemilu menjadi sebuah proses reproduksi kekuasaan yang membutuhkan biaya cukup besar. Tuntutan akan modal ekonomi menjadi sebuah tuntutan yang tidak dapat dipungkiri. Hal ini terkait dengan besarnya biaya yang harus dikeluarkan oleh seorang kandidat dalam sebuah proses yang ada, mulai dari tahap pencapaian menjadi calon legislatif pada tingkat partai sampai pada proses pemilu, sehingga biaya-biaya "ekstra" terkadang harus dikucurkan oleh setiap para kontestan.

Selain itu, modal ekonomi bisa menjadi persyaratan utama ketika individu yang mencalonkan diri sebagai calon legislatif tidak berasal dari internal partai. Namun pada proses pemilu (masa kampanye) para caleg pun harus mengeluarkan biaya yang sangat besar, sehingga dalam pengeluaran ini terkait dengan pembiayaan proses pelaksanaan kampanye. Misalnya, untuk biaya pencitraan baik melalui media maupun melalui baliho, spanduk, brosur dan sebagainya. Untuk membiayai proses kampanye, pengeluaran yang tidak diduga terjadi terkait dengan sosialisasi yang melibatkan masyarakat dengan memberikan uang transport, sebagai upaya untuk membangun relasi dengan para (calon) pendukungnya. Bahkan tidak tanggung-tanggung para kandidat membayar para pendukung untuk berpihak pada dirinya, ketikamelakukan mobilisasi dukungan pada saat menjelang dan berlangsungnya masakampanye.

Oleh karena itu, tidak jarang ditemui bahwa dalam proses kompetisi elektoral, terdapat kandidat-kandidat yang berusaha memenangkan proses pemilu yang ada, dengan mengeluarkan sejumlah uang untuk mempengaruhi atau "membeli" suara para pemilih. Terlepas dari berbagai hal tersebut, modal ekonomi secara mendasar mempunyai arti dan makna yang sangat penting, sebagai penggerak dan pelumasmesin politik yang dipakai oleh tim sukses. Dengan demikian, setiap kampanye seorang calon legislatif membutuhkan uang yang cukup besar, untuk membiayai berbagai kebutuhan seperti mencetak poster, baliho, membayar iklan, menyewa kendaraan untuk mengangkut para pendukung dan berbagai kebutuhan lainnya.

Modal ekonomi pada prinsipnya sangat berguna untuk menentukan langkah gerak dan majunya bagi seorang caleg, untuk menuju kemenangan dalam mekanisme pemilu secara langsung yang pelaksanaanya terus dilakukan dalam lima tahun sekali. Hal ini menjadi penting karena sifat pencalegan adalah individu dan tidak lagi menggunakan sistem nomor urut, sehingga masing-masing caleg melakukan sosialisasi dan berkampanye secara mandiri di daerah yang menjadi pilihannya.

Hal ini, selaras yang disampaikan Littlemore dalam The Communicative Effectiveness of Diferent Types of Communication Strategy mengungkapkan tahapan-tahapan dalam menentukan strategi yaitu: (1) Perencanaan Komunikasi; (2) pelaksanaan Komunikasi; dan (3) Sikap Masyarakat Sesudah Pendekatan Komunikasi. 


\section{Perencanaan Komunikasi}

Berdasarkan tahapan perencanaan komunikasi strategis, pencarian data awal atau melakukan riset menjadi dasar pertimbangan, untuk menentukan tahapan yang dilakukan supaya tujuan bisa tercapai. Untuk mencapai tujuan tahapan perencanaan komunikasi strategis ada dua faktor penting yang digunakan sebagi langkah dalam merumuskan strategi pesan yaitu: (1) tujuan apa yang harus dicapai. Artinya ada beragam tujuan yang bisa dicapai dengan menggunakan program kampanye; dan (2) daya tarik seorang komunikator yang dapat memikat dan mempengaruhi minat publiki.

Dalam melakukan komunikasi persuasif seorang komunikator harus mampu membujuk dan mengarahkan kepada orang lain, terhadap isi pesan yang seseorang akan memproses komunikasi yang dikirim. Ada dua hal yang bisa mempengaruhi bagaimana komunikasi persuasif tersebut diproses, yaitu: (1) motivasi yang disampaikan; (2) isi pesan politik yang akan disampaikan kepada public. Keberhasilan seorang calon legislatif dalam mempengaruhi pemilih sangat bergantung pada kemampuannya mengkondisikan isi pesan politik yang akan disampaikan kepada publik. Persoalannya, apakah isi pesan tersebut menjadi satu kesatuan yang tidak disadari oleh semua calon legislatif, terutama ketika hendak menulis pesan politik bagi konstituennya. Pesan kandidat yang cepat diterima masyarakat adalah isi pesan yang bersumber dari kondisi yang sebenarnya terjadi di masyarakat. Kedekatan isi pesan yang dikonstruksi oleh para kandidat dengan permasalahan yang dihadapi masyarakat membuat masyarakat merasa sangat dekat dengan para kandidat yang sesuai dengan harapannya dapat berjuang dan mencari solusi atas berbagai permasalahan yang dihadapinya.

Oleh karena itu, pesan komunikasi politik harus mudah diakses oleh publik, karena dalam masalah yang sama selalu dipilih yang paling mudah, yang tidak membutuhkan terlalu banyak tenaga atau uang. Pesan yang disampaikan juga harus menggunakan tanda dan sarana yang menghadirkan perbedaan yang nyata (kontra) dengan situasi di sekitarnya, sehingga tampak atau terdengar sangat jelas dan mudah ditangkap oleh indera. Mengangkat persoalan masalah keperluan seorang petani diantaranya, benih padi, pupuk dan pemasarannya serta program sembako murah atau pendidikan gratis, serta infrastrukur jalan adalah isu-isu yang kerap menjadi bahan bagi setiap calon dalam menyusun pesan politik untuk mendekatkan diri dengan pemilih. Sedangkan isu-isu khusus seringkali berasal dari permasalahan spesifik atau khalayak tertentu dalam masyarakat, misalnya isu etnis minoritas, kebebasan beragama atau moralitas masyarakat.

Isu-isu yang sifanya umum dan seringkali diangkat oleh beberapa caleg yang kini menjadi anggota dewan, keuntungannya bisa diterima oleh semua lapisan masyarakat. Meski hanya bersifat retorika normatif yang disampaikan berulang-ulang oleh para caleg, Tetapi dapat dijadikan solusi atas persoalan yang sebenarnya terjadi di masyarakat. Sedangkan isuisu yang bersifat spesifik yang diangkat oleh caleg itu, meski hanya kekurangannya dapat diterima oleh semua lapisan masyarakat, namun menjadi sangat etektif dan mempengaruhi masyarakat. Efektivitas kedua penggolongan isu tersebut, sangat ditentukan pada semakin 
dekatnya pesan politik caleg dalam memvisualisasikan kondisi riil masyarakat, sehingga memberikan alternatif pilihan solusi yang dapat menggugah sikap positif masyarakat terhadap caleg yang bersangkutan. Artinya, isu spesifik yang disampaikan caleg belum tentu bisa membentuk sikap positif masyarakat pemilih, selama caleg yang bersangkutan tidak bisä memvisualisasikan identifikasi dan solusi permasalahan yang dihadapi masyarakat. Sebaliknya isu yang bersifat umum bisa saja mempengaruhi masyarakat tertentu, apabila pesan politik yang dibangun caleg mampu mendekatkan dengan persoalan yang benar-benar terjadi di masyarakat dan mengajak masyarakat untuk mengatasinya.

\section{Pelaksanaan Komunikasi}

Pelaksanaan kegiatan komunikasi politik yang dilakukan masing-masing kandidat banyak menggunakan model Ronald D Smit dan model interaksional yang dikembangkan oleh Wilbur Schramm pada tahun 1954, yang menentukan pada proses komunikasi dua arah diantara para komunikator. Komunikasi yang digunakan komunikasi dua arah, baik dari pengirim ke penerima maupun sebaliknya dari penerima ke pengirim, sehingga terjadi interaksi timbal balik antara keduanya dan seterusnya, terjadi proses melingkar yang menandakan bahwa komunikasi berlangsung.

Dalam komunikasi persuasi yang dilakukan secara interaksional, pada dasarnya antara komunikator dan komunikan mengembangkan potensi manusiawi melalui interaksi sosial dengan mengambil peran orang lain. Oleh karena itu, model interaksi ini antara komunikator (sumber) dan komunikan (penerima) ini memiliki kedudukan yang setara. Satu elemen penting untuk model interaksional ini adalah umpan balik (feedback) atau respon terhadap suatu pesan. Namun, komunikasi tatap muka dapat terjadi ketika komunikator dan komunikan saling berhadapan, sehingga mereka dapat saling melihat. Dengan kata lain, komunikasi tatap muka dapat disebut komunikasi langsung (Soemiratand et al., 2007).

Pendekatan Caleg NasDem untuk mememangkan pemilu yaitu dengan bertemu langsung dan bertatap muka dengan masyarakat pemilih (konstituen) di daerah pemilihannya masing-masing. Pertemuan yang bisa dilakukan melalui berbagai tempat baik secara langsung, mendatangi dari rumah kerumah masyarakat pemilih (door to door), atau didalam tempat acara pertemuan kelompok pengajian, dan pertemuan di berbagai kesempatan lainnya. Dalam pertemuan secara langsung tatap muka yang bersifat resmi seperti undangan di sebuah tempat yang layak misalnya, maka para ketua kelompok pengajian atau kelompok tani dan para ketua paguyuban kepala desa yang diundang harus bisa bertemu secara langsung.

Oleh karena itu, pendekatan komunikasi secara kelompok ini akan ditemui beberapa individu yang tetap sulit menerima, sehingga selanjutnya dilakukan pendekatan komunikasi secara personal yang bisa dilakukan dimana saja, misalnya di sawah, di empang, ditengah hutan atau ditempat yang biasa digunakan masyarakat untuk jagong atau kongkowkongkow. Bahkan beberapa caleg bersedia berkomunikasi empat mata dengan para petani dan masyarakat lain. Keterangan ini dibenarkan oleh para infoman yang lain. Namun, dalam 
pelaksanaan kampanye, ada kesepakatan bahwa tradisi lokal yang mencerminkan budaya lokal memang sarat dengan nilai-nilai kemanusiaan. Caleg yang berhasil dalam menerapkan strategi pesan politiknya, adalah mereka yang benar-benar menyadari pemikiran masyarakat pemilih dalam memahami pesan politik yang diterimanya. Dengan demikian kesadaran ini bersifat timbal balik dengan pesan politik yang disusunnya, sehingga menjadi satu kesatuan yang digunakan caleg dalam melaksanakan kegiatan kampanye. Namun keunggulan pesan kampanye politik caleg, akan ditentukan semakin efektifnya dan berhasilnya mempengaruhi masyarakat pemilih, apabila bersinergi dengan kondisi dan budaya masyarakatnya.

Sejalan dengan pendapat Wilbur Schramm (1955) berhasilnya pesan dalam komunikasi politik setidaknya ada beberapa syarat yang harus dilakukan yaitu: (1) pesan yang direncanakan dan disampaikan dengan metode yang menarik perhatian audiens; (2) pesan harus menggunakan semiotik yang mudah dikenali oleh komunikator dan audiens sehingga keduanya bisa saling paham; dan (3) pesan harus membangkitkan kebutuhan pribadi target dan menyarankan cara untuk memenuhi kebutuhan tersebut. Keempat, pesan harus menyarankan cara untuk memenuhi kebutuhan audiens. Pesan-pesan tersebut jika diterapkan dalam komunikasi politik, maka intensitas pesan politikakan berjalan dengan efektif. Karea sebuah pesan politik menarik perhatian hanya jika membawa harapan atau hasil yang sangat relevan dengan persoalan kebutuhan tersebut.

Tidak mudah mengubah pendapat, sikap dan perilaku seseorang. Seperti ditulis di atas bahwa hal-hal yang mengikat individu dalam penerimaan suatu rangsangan adalah kerangka rujukan (trame otexperience) dan lapangan pengalaman (field of experience).Jadi segala sesuatu yang tidak cocok dengan itu, tidak diterima oleh khalayak. Oleh karena itu, untuk mempengaruhi khalayak,pertama-tama seseorang harus memahami pengalaman dari khalayak tersebut, kemudian menyusun pesan dan metode yang sesuai dengan itu.

Pendekatan terhadap masyarakat yang menggunakan model pendekatan secara kultural atau sosial budaya, proses persuasi yang dilakukan harus berdasarkan bahwa pesanpesan komunikasi dapat digunakan untuk mempengaruhi seseorang. Hal ini dilakukan sebagai dasar individu untuk bertindak. Sedangkan model sosial budaya yang digunakan dalam proses persuasi dapat dilihat pada bagan berikut

Tabel. 3 Model Pendekatan Komunikasi Sosial Budaya

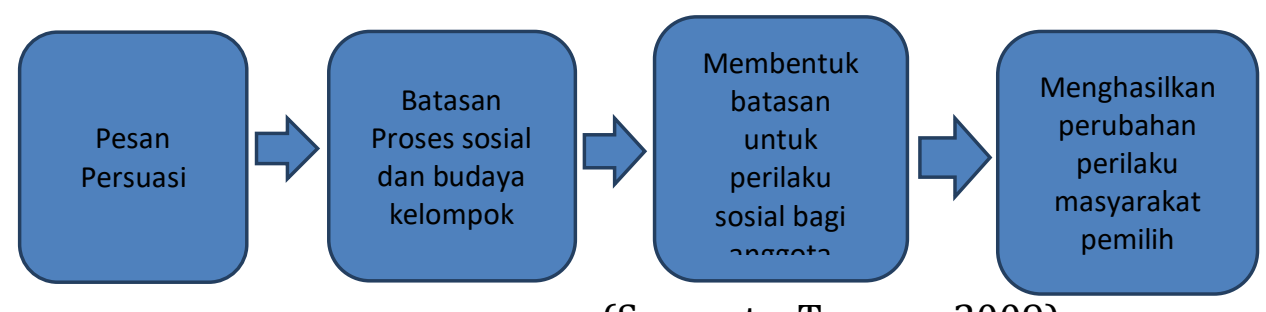

(Suprapto, Tommy, 2009) 
Dari tabel di atas, jelas bahwa untuk melakukan persuasi, sumber persuasi yang memanipulasi bahasa dapat dilakukan dengan cara yang berbeda, untuk mendapatkan isyarat kebersamaan antara sumber dan penerima. Dalam penelitian ini manipulasi bahasa banyak yang dilakukan oleh para calon legislatif pada umumnya, termasuk caleg Partai NasDem adalah "ngopeni" dalam bahasa jawa atau kalau diartikan dalam bahasa Indonesia adalah memelihara komunikasi, yaitu memperlakukan masyarakat pemilih (Konstituen) seperti warga lainnya tetap menjalin komunikasi yang efektif dan baik sehingga terjadi dan timbul ikatan batin antara keduanya.

Pesan persuasif dengan cara ngopeni (memelihara) hubungan komunikasi baik dengan masyarakat pemilih di daerah pemilihan Provinsi Jawa Tengah, ternyata bisa diterima dan diingat dengan baik oleh semua informan yang menjadi sumber ketika dilakukan wawancara. Hubungan emosional berupa ikatan batin antara masyarakat tersebut, ternyata membuat hubungan antara komunikator dan komunikan menjadi lebih erat karena merasa tidak ada perbedaan kelas social. Istilah "ngopeni" ini ternyata juga menjadi sangat populer di media lokal maupun nasional, terbukti dari banyaknya wawancara dengan beberapa caleg yang berhasil menjadi anggota DPR yang peneliti lakukan sebagai objek penelitian, menjadi seorang tokoh yang terkenal karena selama belum menjadi anggota parlemen, sudah sering melakukan investasi sosial dan selalu turun ke bawah menyerap aspirasi masyarakat. Dengan prinsip "nguwongke dan ngopeni" inilah muka pesan komunikasi bisa diterima dengan baik oleh komunikan karena sesuai dengan budanya.

Dari hasil penelitian menunjukkan bahwa komunikasi strategis yang dilakukan beberapa caleg, dengan mengoptimalkan berbagai pendekatan budaya yang disesuaikan dengan karakter lokal, bisa mengangkat pesan "ngopeni"'. Padahal, ngopeni artinya memelihara hubungan yang baik supaya terjadi adanya ikatan batin dan tidak membedakan antara masyarakat yang satu dengan lainnya. Masyarakat di daerah pemilihan Jawa Tengah yang sebagian besar pekerjaannya sebagai petani, ternyata mempunyai berbagai permasalahan yang timbul sehingga perlu adanya penyelesaiannya.

Namun demikian, dalam mempengaruhi sikap,pendapat dan perilaku masyarakat pemilih, cara-cara pendekatan komunikasi seperti yang dipaparkan sebelumnya di atas, terdapat satu lagi model pendekatan dengan komunikan yang harus dilakukan seorang caleg, yaitu pendekatan intervensi sosial. Menurut seorang informan motede ini belun penah digunakan di daerah lain di Indonesia, apalagi belum ada yang menggunakan cara seperti ini. Misalnya, kegiatan komunikasi dengan intervensi sosial dalam penelitian ini adalah melakukan pertemuan di warung di tepi jalan yang melibatkan masyaräkat petani.

Selain itu, pendekatan yang dilakukan masing-masing caleg dengan cara-cara mendatangi undangan dari berbagai kelompok masyarakat, seperti kelompok pengajian dan undangan nikahan dan lain-lainnya. Dengan cara menghormati atas undangan yang dilakukan oleh kelompok masyarakat tersebut, setidaknya bisa merubah pandangan dan pendapatnya. 
Namun supaya masyarakat pemilih luluh hatinya pendekatan komunikasi yang dilakukan caleg adalah mendatangi rumahnya atau door to door. Dengan mengunjungi rumahnya tersebut, sebagai langkah terakhir supaya masyarakat pemilih terjadi ikatan batin sehingga memilihnya dalam pemilihan legislatif.

\section{Sikap Masyarakat Sesudah Pendekatan Komunikasi}

Perubahan sikap masyarakat yang mempunyai hak pilih di daerah pemilihan di Jawa Tengah, pada umumnya menjatuhkan pilihan kepada partai atau kandidat tertentu yang memiliki program, yang berkaitan dengan kepentingan sosial dan demografinya. Para caleg NasDem dalam melakukan kontestasi di daerah pilihannya yang berhasil memenangkan pemilu legislatif, ternyata banyak melakukan pendekatan komunikasi persuasif dengan beberapa tim suksesnya, relawan dan jaringan opinion leaders secara terus menerus bekerja dengan keras dan kesabaran yang dilakukan dengan berbagai cara.

Pendekatan yang dilakukan dengan mendatangi dan melakukan silaturrahmi kepada tokoh masyarakat, tokoh agama dan tokoh pemuda dengan menjelaskan visi, misi dan program partai, akhirnya pesan politik yang disampaikan bisa diterima dengan baik. Pesan yang dapat menimbulkan perhatian adalah pesan yang mudah diperoleh masyarakaat, karena itu harus menyolok perbedaannya dengan pesan-pesan yang lain. Kedua hal itu ditujukan terutama dalam penggunaan tanda-tanda komunikasi dan penggunaan medium, yang disertai pemberian bantuan berupa kebutuhan yang diperlukan dari beberapa kelompok yang berhasil didatangi tokoh agama dan tokoh pemuda.

Perubahan sikap masyarakat yang terjadi karena adanya relevansi tema atau materi program yang cenderung berlangsung lama, sehingga sulit berubah dan perilaku yang muncul mudah diperkirakan menurut Jowett\& O'Donnel, (2006, hlm. 209).

Perubahan sikap pada para pemilih (masyarakat) sebenarnya muncul dalam bentuk perubahan sikap mereka, yang pada awalnya tidak tertarik terhadap kebijakan atau program partai dan calegnya, namun setelah mengerti apa yang akan disampaikan dan diperjuangkan akhirnya mempunyai sikap untuk memiihnya. Perubahan sikap masyarakat pemilih bisa terjadi ketika program partai dan calegnya, terus menerus melakukan komunikasi politik secara rutin mendatangi rumahnya, sehingga mendapat perhatian setelah dilakukan pendekatan komunikasi persuasif oleh para caleg NasDem dan tim suksesnya secara terus menerus hingga menjelang pencoblosan. Perubahan sikap masyarakat pemilih seperti ini sangat terkait dengan pendekatan komunikasi yang dilakukan caleg, melalui pendekatan budaya dengan istilah ngajeni, ngopeni serta nguwongke wong yaitu menghormati dan memanusiakan dalam memperlakukan mereka seperti dengan masyarakat lainnya.

Jadi kesimpulannya bahwa dalam komunikasi politik yang bertujuan mengubah sikap khalayak kepadanya harus disodorkan konsepsi yang positif, bukan konsepsi yang negatif, memberikan hal-hal yang baik kepada khalayak yang sama sekali tidak mencela pendapatpendapat dan sikap-sikapnya selama ini mengutuip pendapat Arifin (2011, hlm. 251). Hal 
lain yang dilakukan dengan menggunakan pendekatan komunikasi tatap muka (face to face) dengan melalui undangan pertemuan, baik melalui pertemuan RT, RW dan pertemuan dalam kelompok pengajian ibu-ibu baik secara kelompok maupun secara personal untuk individuindividu yang sulit didekati. Bahkan pendekatan dengan cara intervensi sosial harus dilakukan, bila memang harus diterapkan sebagai upaya untuk mempengaruhinya.

Jika perlu para caleg melakukan kunjungan kerumah langsung dengan jalan door to door, sehingga pendekatan yang dilakukan bener- benar bisa menyentuh hatinya sehingga bisa berubah untuk memilihnya. Kegiatan pendekatan komunikasi persuasif yang dilakukan para caleg ini, harus juga dibantu oleh para tim suksesnya dan jaringan relawan serta tokoh masyarakat melakukan pendekatan secara manusiawi, sehingga mendapat perhatian secara tulus dan ikhlas. Untuk memberikan supaya ada rasa timbul kepercayaan lagi, bila mewujudkan kampanye terbuka yang menghadirkan juru kampanye dari tokoh politik, sehingga memberikan pencerahan dan memilih caleg yang bersangkutan. Pendekatan lainnya dalam memaparkan program-programnya harus benar- benar diwujudkan, jangan hanya memberikan janji-janji yang tidak direalisasikan dengan baik. Pendekatan yang dilakukan dengan berbagai terobosan dan kreativitas, akhirnya bisa membuat para caleg tersebut dipilih oleh masyarakat pemilih dengan penuh ikhlas dan legawa untuk menjadi perwakilan di parlemen.

Dengan demikian berhasilnya seorang caleg yang bisa melenggang ke kursi parlemen tidak lepas, dari strategi, metode dan cara-cara yang kreatif dalam melakukan pendekatan terhadap masyarakat pemilih. Strategi perencanaan komunikasi seperti kampanye, pesan , marketing politik dan pendekatan komunikasi secara pesuasif terhadap masyarakat pemilih, merupakan bagian yang tidak terpisahkan dari kegiatan para caleg.

Untuk mendapatkan dukungan dari masyarakat seorang caleg tidak lepas adanya modalitas, yaitu modal politik, modal sosial dan modal ekonomi. Ketiga modalitas tersebut bisa berubah menjadi kemenangan dalam pemilu, melalui suatu strategi konversi modalitas menjadi suara (vote) yang dilakukan oleh caleg. Ketiga modal itu juga bisa berdiri sendirisendiri tanpa adanya keterkaitan antara yang satu dengan yang lain. Di antara ketiganya seringkali terkait satu sama lain, yaitu setiap calon memiliki peluang besar terpilih manakala memiliki akumulası lebih dari satu modal. Oleh karena itu, semakin besar calon yang mampu mengakumulasi tiga modal tersebut menjadi suara (vote), semakin berpeluang untuk menang dalam pemilu.

Modal sosial seperti yang dijelaskan didepan memıliki karakter dinamis, sehingga dapat dikonversikan atau bertransformasi menjadi modal politik. Selanjutnya modal ekonomi disebut-sebut sebagai akar berbagai modalitas, karena mampu dikonversikan menjadi dua modal yang lain yaitu modal sosial dan modal politik. Namun dalam hubungannya dengan strategi politik, keunggulan modal sosial dan modal ekonomi merupakan sebuah hal mendasar yang dapat dijadikan sebagai salah satu strategi politik untuk memenangkan sebuah proses konstetası politik. 


\section{Acknowledgment}

Hasil penelitian ini, menyatakan bahwa seluruh narasumber memiliki modalitas yang cukup bervariasi serta motivasi dan kemauan yang tinggi, untuk bisa berhasil menjadi pemenang dengan cara mendekati masyarakat pemilih yang mempunyai hak pilih. Para caleg tidak hanya menggunakan jalur komunikasi langsung untuk melakukan strategi komunikasi politik, tetapi juga melakukan pendekatan komunikasi antarpribadi, komunikasi kelompok dengan cara mendatangi undangan pengajian dalam melakukan proses persuasinya. Selain dengan cara ini, juga dilakukan pendekatan door to door, sehingga bisa mayakinkan terhadap masyarakat yang menjadi sasarannya.

Selain itu, para caleg yang sekarang menjadi anggota dewan DPRD Provinsi Jawa Tengah, banyak menggunakan pendekatan komunikasi persuasif, baik antar pribadi dan kelompok menentukan pilihannya dalam memilih caleg yang bisa mewakilinya. Diperoleh hasil bahwa komunikasi dengan bertemu langsung dan bertatap muka secara pribadi, merupakan alat yang paling dominan untuk membentuk sikap, pendapat dan perilaku positif masyarakat pemilih terhadap caleg dan program partai. Kontestasi Pemilu 2019 dengan cara melakukan komunikasi melalui pendekatan tradisional yaitu dengan bertemu secara personal masyarakat awan, komunitas organisasi, tokoh masyarakat, Para Kiai, mantan penjabat, RT dan RW yang dilakukan dengan model kunjungan ke rumah-rumah, 'nguwongke uwong',

Lebih lanjut, seluruh masyarakat pemilih mempunyai motivasi, partisipasi dan kemauan yang tinggi untuk menerima persuasi terhadap caleg dengan program partai. Para caleg yang terpilih ini, selain menggunakan opinion leaders-nya juga menggunakan jalur komunikasi langsung dalam menyampaikan pesan politiknya kepada masyarakat pemilih. Penerapan strategi komunikasi politiknya para caleg juga menggunakan strategi door to door, pendekatan tradisional yaitu dengan bertemu secara personal masyarakat awan, komunitas organisasi, tokoh masyarakat, Para Kiai, mantan penjabat, RT dan RW yang dilakukan dengan model kunjungan ke rumah-rumah.

Dengan demikian, proses persuasi di sini merupakan alat yang paling dominan, digunakan untuk membentuk sikap para pemilih terhadap caleg yang bersangkutan. Dengan cara seperti ini serta menjalin komunikasi secara intensif, juga ngopeni dan 'nguwongke wong' bisa memberikan rasa percaya diri sehingga timbul rasa ikhlas untuk menentukan pilihannya.

Setiap penelitian pada umumnya berpedoman atau dipandang sebagai proses dan hasil penelitian terdahulu yang telah ada. Pada penelitian ini, peneliti melihat beberapa temuan penelitian yang mengangkat permasalahan yang selaras akan penelitian ini yaitu : (1) Peneliti menggunakan strategi komunikasi politik melalui S-M-C-R. Menggunakan teori S-M-C-R ini dalam strategi komunikasi politik yang diterapkan calon legislatif PKB; (2) Strategi Kampanye Calon Legislatif Pemula DPR RI dari Partai Persatuan Pembangunan (PPP); (3) 
Strategi Kampanye Anggota Legislatif DPRD Kabupaten Bantul Dapil V Pada Pileg 2014; dan (4) Komunikasi Politik dengan Pendekatan Sosial Keagamaan dan Sosial Kemasyarakatan.

Dari keseluruhan jurnal yang telah peneliti paparkan, perbedaan penelitian ini dan penelitian terdahulu dari penggunaan strategi politiknya. Selain itu, subjek penelitian pada calon anggota Partai NasDem yang sekarang menjadi anggota legislatif di DPRD Provinsi Jawa Tengah.

Sementara itu, Teori yang digunakan pada penelitian yaitu Elaboration Likelihood Model Theory (ELM) dari Petty dan Cacciopo, pengumpulan data menggunakan observasi langsung, observasi partisipasif, dan dokumentasi. Teknik analisis penelitian ini menggunakan proses coding. Oleh karena itu, penelitian ini merupan hal yang baru karena belum ada yang meneliti Taktik Komunikasi Politik Partai Nasdem dalam Memenangkan Pemilu Legislatif 2019.

\section{Bibliography}

Abdullah, Zein. (2008). Strategi Komunikasi Politik dan Penerapannya, Simbiosa Rekatama Media, Bandung.

Alfian. (1993).Komunikasi Politik dan Sistem Politik Indonesia. Gramedia, Jakarta.

Ali , Novel. (1999). Peradaban Komunikasi Poltik. Bandung:Remaja Rosdakarya.

AP, Sumarno \& Yeni Lukiswara, (1992). Pengantar Studi Ilmu Politik.Bandung : PT Citra Aditya Bakti.

Arifin, Anwar. (2011).Komunikasi Politik: Filsafat-paradigma - teori - tujuan - strategi dan komunikasi politik Indonesia.Yogyakarta: Graha Ilmu.

Budhiarjo, Miriam. (2000). Pengantar ilmu Politik. Jakarta: Gramedia.

Firmanzah, (2008). Mengelol Partai Politik.Jakarta : Yayasan Obor Indonesia.

Gaffar, Afan.( 2006). Politik Indonesia.Yogyakarta : Puataka Pelajar.

Cangara, Hafied. (2011). Komunikasi Politik : Konsep, teori dan Strategi.Jakarta: PT. Rajagrafindo Persada.

Cangara, Hafied. (2013).Perencanaan dan strategi Komunikasi. Jakarta: Rajawali Pers.

Creswell, John W. (2011).Qualitative Inquiry and Research Design. Second Edition California : Sage Publication.

Effendy, Onong Uchjana, (2010), Ilmu Komunikasi Teori dan Praktek. Bandung: PT. Remaja Rosdakarya.

EM Griffin. (2012). A First Look At Communication Theory. Mc Graw Hill

Firmanzah. (2008). Mengelola Partai Politik: persaingan dan Positioning Idiologi Politik. Jakarta: Yayasan Obor Indonesia.

Firmanzah .(2008) Marketing Politik; Antara Pemahaman dan Realitas. Jakarta: Yayasan Obor Indonesia.

Heryanto, G., \& Zarkasy, I. (2012). Public Relations Politik. Bogor: Ghalia Indonesia. 
Little John, Stephen W \& Foss Karen A. (2009). Teori Komunikasi.Jakarta: Salemba Humanika.

Little John, Stephen W \& Foss Karen A. (2008).Theories of Human Communication. Ninth Edition. Belmont, CA : Thomson Wadsworth.

Marianne Dainton and Elaine D.Zelley, (2011). Applying Communication Theory for Professional Life; a Pratical Introduction. Oaks :SagePublications.

Markus,Gunawan. (2008) Buku Pintar calon anggoa Legislatif.Jakarta : Visimedia.

Mas'oed, Moohtar dan Callin Mac Andrewa. (2009). Perbandingan Sistem Politik. Cetakan ke-17.Yogyakarta: Gajah Mada Press.

Meoloeng, Lexy J M.A. (2009). Metodologi Penelitian Kualitatif. Bandung : PT.Remaja Rosdakarya.

Morissan. (2013). Teori Komunikasi ; Individu Hingga Massa. Jakarta: Kencana Prenada Media.

Mulyana Dedy, (2011) Imu komunikasi suatu pengantar, Remaja Rosdakarya, Bandung.

Nimmo, san (2000).Komunikasi Politik : Khalayak dan Efek. Bandung: PT Remaja Rosdakarya.

Ramdansyah. (2010). "Sisi Gelap Pemilu 2009 Potret Aksesori Demokrasi Indonesia".

Sastrosatmodjo, Sudjono (1995). Perilaku Politik. Semarang: IKIP Semarag Press.

Surbakti, Ramlan . (2010). Memahami Ilmu politik. Jakarta :Grasindo Press. 